Jpn. J. Hosp. Pharm.

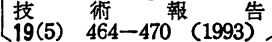

Nephelometric Immunoassay 法によるフェノバルビタール

\title{
およびカルバマゼピンの血中漊度測定 $\dagger^{1}$
}

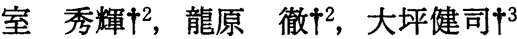 \\ 鳥取大学医学部附属病院薬剤部 $\dagger^{2}$ \\ 九州大学医学部附属病院薬剂部 $\dagger^{3}$
}

\section{Quantitative Determinations of Phenobarbital and Carbamazepine in Serum by Nephelometric Immunoassay $\dagger^{1}$}

\author{
HIDEKI MURO $\dagger^{2}$, TOHORU TATSUHARA $\dagger^{2}$, KENJI OTSUBO $\dagger^{3}$ \\ Department of Pharmacy, Tottori University Hospital $\dagger^{2}$ \\ Department of Pharmacy, Kyushu University Hospital $\dagger^{3}$
}

(Received April 21, 1993)

(Accepted July 14, 1993 )

An automated rate nephelometric assay (Beckman Array 360 System) for phenobarbital (PB) and carbamazepine (CBZ) was evaluated. The assay offers measuring ranges of 5-120 $\mathrm{gg} / \mathrm{ml}$ serum for $\mathrm{PB}$ and $2-40 \mathrm{\mu g} / \mathrm{ml}$ for $\mathrm{CBZ}$. The coefficients of variation for within-run and between-run precision for both $\mathrm{PB}$ and $\mathrm{CBZ}$ were $<5.0 \%$. Test results were not significantly affected by bilirubin-unconjugated (up to $19.2 \mathrm{mg} / \mathrm{dl}$ ), bilirubin-conjugated $(21.3 \mathrm{mg} / \mathrm{dl}$ ), hemoglobin $(540 \mathrm{mg} / \mathrm{dl})$, turbidity $(2070$ units), or other antiepileptic drugs. The method produced satisfactory results in dilution tests. Quantitative results obtained by the Array 360 assay on serum samples from patients were compared with those obtained by the fluorescence polarization immunoassay (FPIA) and homogeneous enzyme immunoassay (EMIT) methods. The results correlated well with FPIA ( $r=0.996$ and 0.981 for $\mathrm{PB}$ and $\mathrm{CBZ}$, respectively) and EMIT $(r=0.994$ and 0.983$)$. The Array 360 assay was concluded to be an appropriate and quick method for $\mathrm{PB}$ and $\mathrm{CBZ}$ determination.

Keywords—-phenobarbital; carbamazepine; therapeutic drug monitoring; nephelometric assay

はじめに

フェノバルビタール (PB) 拈よびカルバマゼピ

$\dagger^{1}$ 本報は日本薬学会第113年会 (大阪, 1993年 3 月) で発表.

$\dagger^{2}$ 鳥取県米子市西町 36-1; 36-1, Nishi-Machi, Yonagoshi, Tottori, 683 Japan

$\dagger^{3}$ 福岡市東区馬出3-1-1; 3-1-1, Maidashi, Higashiku, Fukuokashi, 812 Japan
ン（CBZ）は抗てんかん薬として広く用いられて いる薬剤である．これら薬物の血中濃度測定には ガスクロマトグラフ法 ${ }^{1,2)}$, 高速液体クロマトグ ラフ法3,4)などの報告もあるが，一般には蛍光偏 光免疫測定法 (FPIA 法 $)^{5,6)}$, 酵素免疫 測 定 法 $(\mathrm{EMIT} \text { 法 })^{7,8)}$ などによる全自動血中濃度測定装 置が用いられ，臨床的にもモニタリングが定着し つつある・ 
一方，免疫反応で生成する抗原抗体複合体によ る散乱光増加速度の最高变化速度 (peak rate) を捕らえ，抗原濃度に変換する Nephelometric immunoassay 法は，近年血中微量蛋白成分 （アポ蛋白9，免疫グロブリン10)など）の測定に 応用されている。本法は Endpoint Assay に比 べて処理能力に優れ，またバックグラウンドの影 響を受けにくいとされている。

今回, Nephelometric immunoassay 法を原 理とする $\mathrm{PB}$ および $\mathrm{CBZ}$ の血中濃度測定用全 自動蛋白化 学分析装置 Beckman Array 360 System (Array 360 ; Beckman 社) が開発さ れ，試用する機会を得たので，その測定精度，共 存物質の影響, 他の抗てんかん薬との交差反応, 希釈直線性などを検討するとともに，FPIA 法， EMIT 法による測定値との相関性についても検 討したので報告する.

な拈，本法の試薬の多価抗原はフポフェリチン にハプテン (PB， CBZ) を共有結合させたもの で，抗体はヤギ血清より得られたものである.

\section{実 験 の 部}

\section{1. 測定試料}

測定試料としては鳥取大学医学部附属病院にお。 いて PB（100検体）または CBZ (69検体) の投
与を受けているてんかん患者の血清を用いた。

\section{2. 装田および試薬}

1) Array 360法 アレイ全自動蛋白化学分析 装置 Array 360 System (ベックマン) を用い て測定した。試薬はベックマン社より提供された フェノバルビタール試薬キット，カルバマゼピン 試薬キット，薬物キャリブレータキット执よび希 釈用 Buffer 溶液を用いた，検量線は初日のみに 作成し, 以後の実験期間中（2 週間）もそれを用 いた。な扮希釈用 Buffer 溶液以外の試薬は 6一 $8^{\circ} \mathrm{C}$ で保存した。

2） FPIA 法 TDX 全自動蛍光偏光免疫測定 装置（ダイナボット）を用い，試薬の他，キャリ ブレータ，コントロールを用いた。検量線は測定 毎に作成した。

3） EMIT 法 エミットクリニカルプロセッ サー Model CP-5000（エミット）を用いて測定 した. 試薬はェミットフェノバルビタールアッセ イ $\mathrm{S}$, エミットカルバマゼピンフッセイ（モノク ローナル), エミット AED キャリブレータセッ トを用いた，検量線は測定毎に作成した。

4）その他の試薬 カルバマゼピン，エトスク シミド，フェノバル゙タール，フェニトイン，プ リミドン（いずれも和光純薬；生化学用）および 共存物質干渉チェック・A（国際試薬）は市販品

Table 1. Phenobarbital and Carbamazepine Precision Studies Obtained by Array 360

\begin{tabular}{lcccc}
\hline & $\begin{array}{c}\text { Mean } \\
(\mu \mathrm{g} / \mathrm{ml})\end{array}$ & $\begin{array}{c}\text { S.D. } \\
(\mu \mathrm{g} / \mathrm{ml})\end{array}$ & $\begin{array}{c}\text { C.V. } \\
(\mathrm{z})\end{array}$ & $\mathrm{n}$ \\
\hline $\begin{array}{l}\text { Within-Run Precision } \\
\text { Phenobarbital }\end{array}$ & 19.5 & 0.65 & 3.35 & 10 \\
& 10.1 & 0.37 & 3.65 & 10 \\
& 15.5 & 0.56 & 3.61 & 10 \\
Carbamazepine & 7.4 & 0.34 & 4.57 & 10 \\
& & & & \\
Between-Run Precision & & & & \\
Phenobarbital & 20.6 & 0.80 & 3.87 & 6 \\
& 10.4 & 0.42 & 4.01 & 6 \\
Carbamazepine & 15.8 & 0.28 & 1.78 & 6 \\
& 7.4 & $0.32 \cdots$ & 4.36 & 6 \\
\hline
\end{tabular}



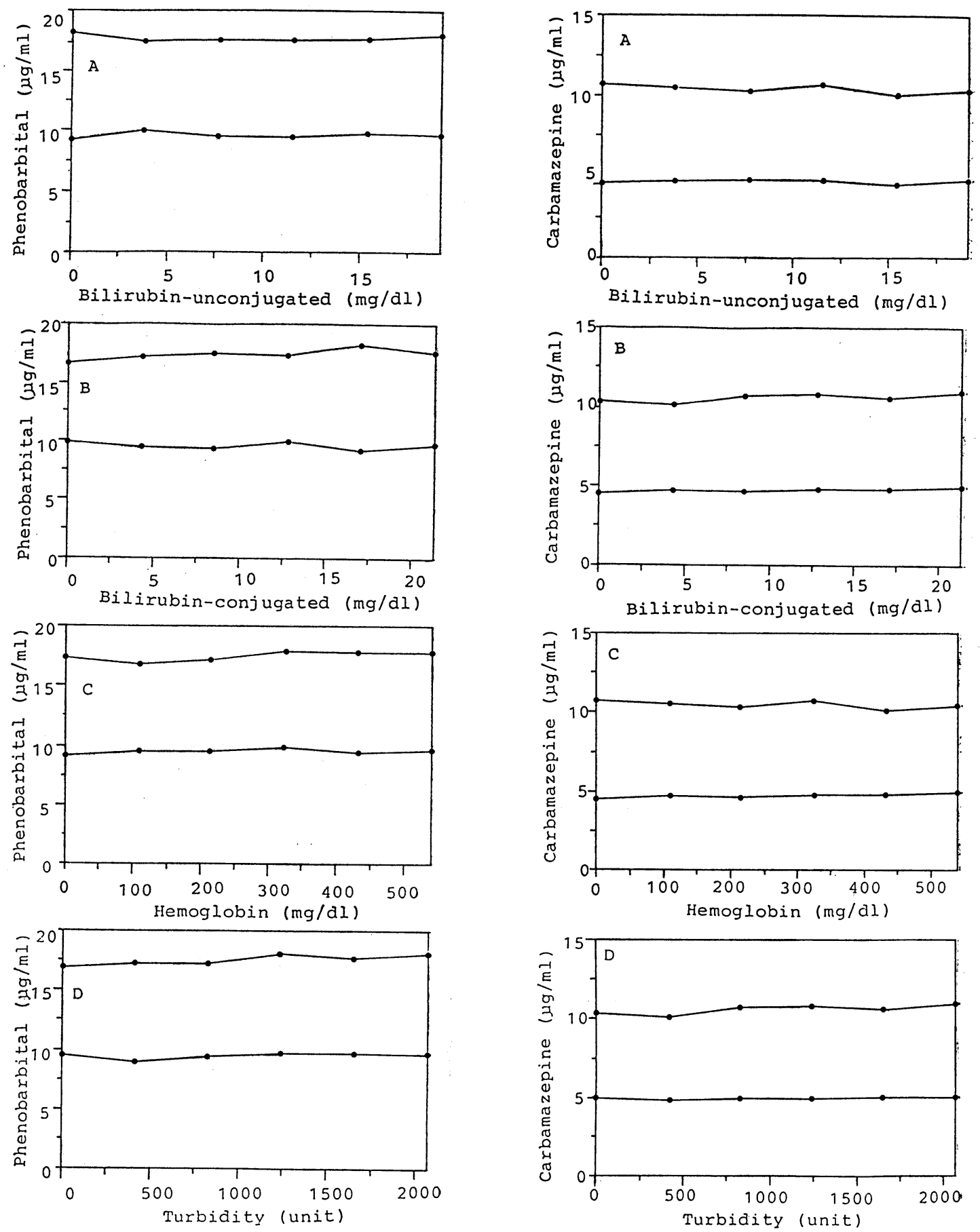

Fig. 1. Interference from Bilirubin-unconjugated (A), Bilirubin-conjugated (B), Hemoglobin (C) and Turbidity (D) on Array 360 Assays for Phenobarbital

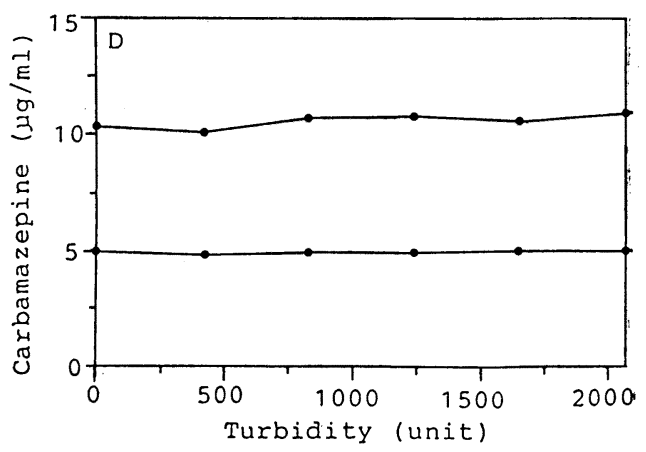

Fig. 2. Interference from Bilirubin-unconjugated (A), Bilirubin-conjugated (B), Hemoglobin (C) and Turbidity (D) on Array 360 Assays for Carbamazepine 
を用いた。ゾニサミドは大日本製薬より提供を受 计た。

\section{結果}

\section{1. 信頼性}

$\mathrm{PB}$ および $\mathrm{CBZ}$ の各濃度 $(\mathrm{PB}, 20,10 \mu \mathrm{g} / \mathrm{ml}$; $\mathrm{CBZ}, 15,7.5 \mu \mathrm{g} / \mathrm{ml}$ ) に打㤝る Array 360 の測 定値の日内再現性は PB または $\mathrm{CBZ}$ 添加血清 を10回同時測定して検討した. 変動係数は各濃度 とも5\%以下の良好な再現性が得られた（Table 1). 日間再現性は, 2 濃度の $\mathrm{PB}$ およびCBZ 添 加血清について10日間にわたり 6 回測定して検討 した. 変動係数は各濃度とも5\%以下の良好な再 現性が得られた（Table 1).

\section{2. 共存物質の影郂}

定量を妨害すると考えられ.る血清中の共存物質 として遊離ビリルビン，抱合型ビリルビン，へモ グロビン，乳ビを用い Array 360 法への影響に ついて検討した，PB および $\mathrm{CBZ}$ に対し，遊離 ビリルビン $19.2 \mathrm{mg} / \mathrm{dl}$, 抱合型ビリルビン 21.3 $\mathrm{mg} / \mathrm{dl}$, へモグロビン $540 \mathrm{mg} / \mathrm{dl}$, 乳ビ 2070 度ま でいずれも影響はみられなかった（Fig. 1，2）。

\section{3. 希釈直線性}

高濃度の PB $(50,30 \mu \mathrm{g} / \mathrm{ml})$ および CBZ (25, $15 \mu \mathrm{g} / \mathrm{ml}$ ) 添加血清を調製し，それぞれを希釈用 Buffer 溶液で希釈し, Array 360 法の直線性を

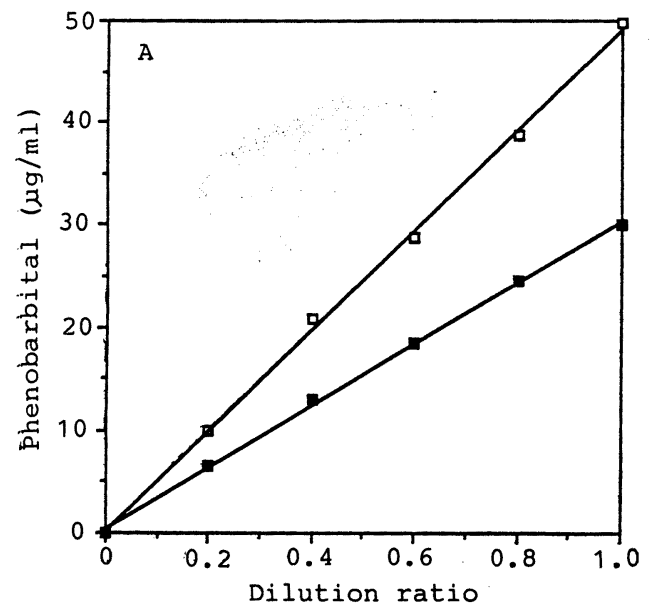

検討した。いずれもほぼ原点を通る直線が得られ た (Fig. 3).

\section{4. 交差反応}

他の抗てんかん薬との交差反応を検討する目的 で, 有効治療濃度の上限值と思われる PB (20 $\mu \mathrm{g} / \mathrm{ml}), \mathrm{CBZ}(10 \mu \mathrm{g} / \mathrm{ml})$, エトスクシミド $(100$ $\mu \mathrm{g} / \mathrm{ml}), \quad ソ ゙ ニ サ ミ ト ゙ ~(100 \mu \mathrm{g} / \mathrm{ml})$ ， バルプロ酸 $(100 \mu \mathrm{g} / \mathrm{ml}), フ ェ ニ$ フン $(20 \mu \mathrm{g} / \mathrm{ml})$, プリミ ドン $(12 \mu \mathrm{g} / \mathrm{ml})$ 添加血清を調製し, Array 360 法で測定した. PB $(20.3 \mu \mathrm{g} / \mathrm{ml})$ で97.5-104.9 $\%, \mathrm{CBZ}(8.1 \mu \mathrm{g} / \mathrm{ml})$ で95.1-101.2\%の測定值 が得られ，他の抗てんかん薬との交差反応は認め られなかった (Table 2).

\section{FPIA 法および EMIT 法との相関性}

Array 360 法による PB の測定值 $\mathrm{y}_{1}$ と FPIA 法による測定值 $\mathrm{x}_{11}$ との間には, 回帰式 $\mathrm{y}_{1}=$ 9.974 $\mathrm{x}_{11}+0.348$, 相関係数 $\mathrm{r}=0.996 \quad(\mathrm{n}=100)$ （Fig. 4 A) ; EMIT 法による測定值 $\mathrm{x}_{12}$ との間に は, 回帰式 $\mathrm{y}_{1}=0.970 \mathrm{x}_{12}+0.438$, 相関係数 $\mathrm{r}=$ $0.994(n=100)$ (Fig. 4 B) が得られた。なお, 測定值 $\mathrm{x}_{11}$ と $\mathrm{x}_{12}$ の間では, $\mathrm{x}_{11}=1.017 \mathrm{x}_{12}-0.204$, 相関係数 $\mathrm{r}=0.996$ であった.

Array 360 法による CBZ の測定値 $\mathrm{y}_{2}$ と FPIA 法による測定値 $\mathrm{x}_{21}$ との間には, 回帰式 $\mathrm{y}_{2}=1.037$ $\mathrm{x}_{21}-0.112$, 相関係数 $\mathrm{r}=0.982(\mathrm{n}=69)$ ）(Fig. $5 \mathrm{~A}$ ）；EMIT 法による測定值 $\mathrm{x}_{22}$ との間には，回

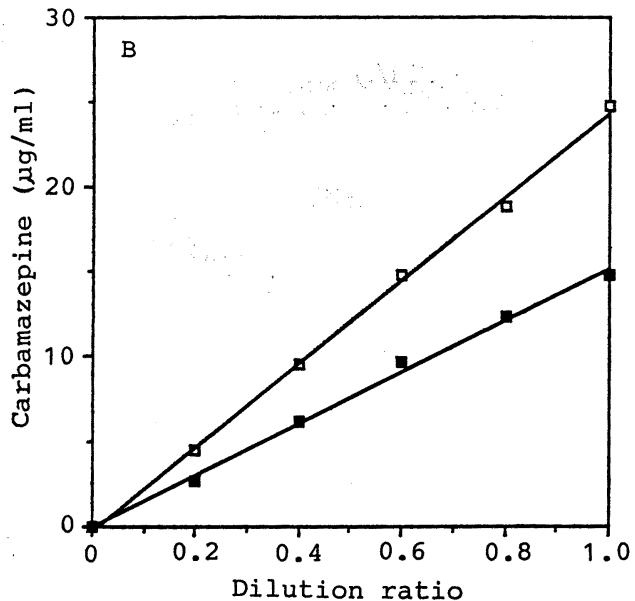

Fig. 3. Effect of Sample Dilution with Buffer on Linearity for Phenobarbital (A) and Carbamazepine (B) 
Table 2. Cross-Reactivity of Other Anticonvulsant Drugs for Phenobarbital and Carbamazepine in the Array 360 Assays

\begin{tabular}{|c|c|c|c|c|c|}
\hline \multicolumn{2}{|l|}{ Drug taken } & \multicolumn{2}{|c|}{ Phenobarbital } & \multicolumn{2}{|c|}{ Carbamazepine } \\
\hline & $\begin{array}{l}\text { Conc. } \\
\text { ( } \mathrm{g}_{\mathrm{g} / \mathrm{m} I)}\end{array}$ & $\begin{array}{l}\text { Conc. } \\
(\mu \mathrm{g} / \mathrm{mI})\end{array}$ & $\begin{array}{c}\text { Recovery } \\
(z)\end{array}$ & $\begin{array}{l}\text { Conc. } \\
(\mu \mathrm{g} / \mathrm{mI})\end{array}$ & $\begin{array}{c}\text { Recovery } \\
(z)\end{array}$ \\
\hline None & 0 & 20.3 & 100.0 & 8.1 & 100.0 \\
\hline Carbamazepine & 10 & 20.0 & 98.5 & -- & -- \\
\hline Ethosuximide & 100 & 19.9 & 98.0 & 7.9 & 97.5 \\
\hline Phenobarbital & 20 & -- & -- & 7.8 & 96.3 \\
\hline Phenytoin & 20 & 21.3 & 104.9 & 7.7 & 95.1 \\
\hline Primidone & 12. & 20.7 & 102.0 & 7.7 & 95.1 \\
\hline Valproic Acid & 100 & 19.8 & 97.5 & 7.8 & 96.3 \\
\hline Zonisamide & 50 & 20.1 & 99.0 & 8.2 & 101.2 \\
\hline
\end{tabular}
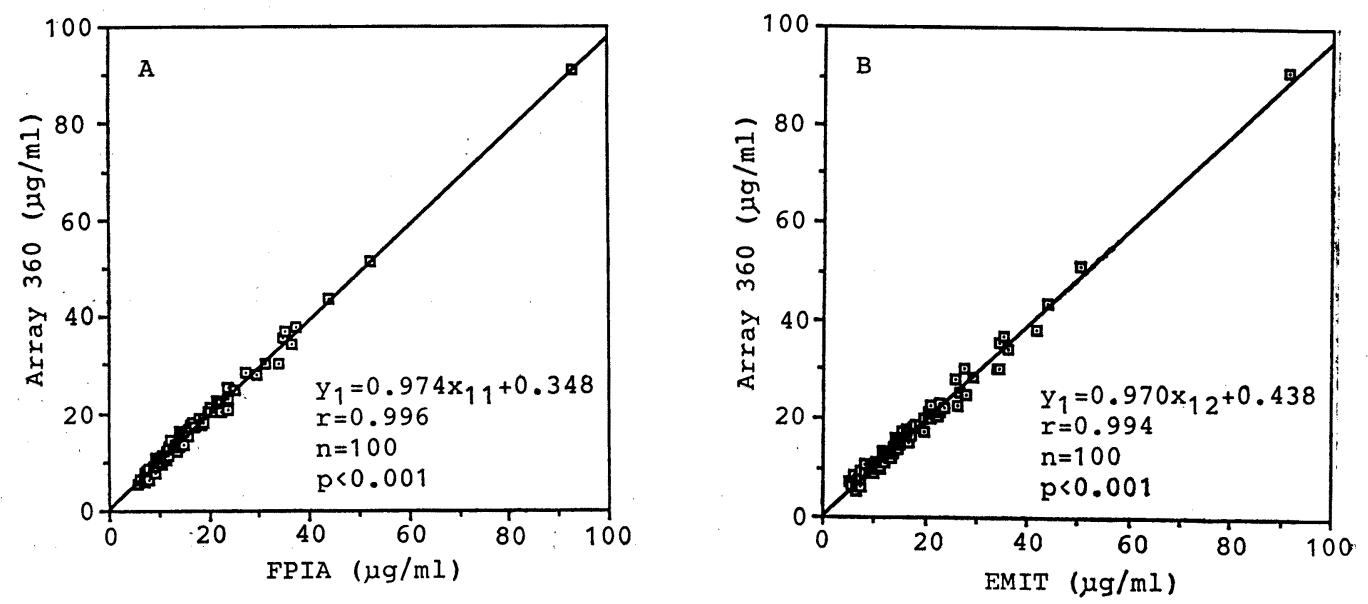

Fig. 4. Correlations among the Array 360 System, Fluoresense Polarization Immunoassay (FPIA) (A) and Homogeneous Enzyme Immunoassay (EMIT) (B) for the Determination of Phenobarbital

㷌式 $\mathrm{y}_{2}=1.031 \mathrm{x}_{22}+0.247$, 相関係数 $\mathrm{r}=0.984$ $(n=69)$ （Fig. 5 B）が得られた.なお, 測定值 $x_{21}$ と $\mathrm{x}_{22}$ の間では, $\mathrm{x}_{21}=0.971 \mathrm{x}_{22}-0.003$, 相関係 数 0.973 であった.

\section{考察}

Array 360 法に括ける PB および $\mathrm{CBZ}$ の測 定は日間・日内変動とも $5 \%$ 以下とほぼ満足でき る結果であり，希釈直線性も良好であった。 また 他の抗てんかん薬との交差反応もほとんど認めら れず，血清中の共存物質の影響も受けなかった。
$\mathrm{CBZ}$ 投与患者の血清中には主代謝物である CBZ-10，11-エポキサイドが CBZ 濃度の 約 15 \%含まれていると報告されているが11)，今回は Array 360法に対するこのエポキサイドの交差反 応については検討しなかった，一方，FPIA 法に よるエポキサイドの交差反応性は $20 \%$ 程 度 ${ }^{12)}$, EMIT 法では $\mathrm{CBZ}$ 濃度 $8.0 \mu \mathrm{g} / \mathrm{ml}$ に対しエポ キサイド $50 \mu \mathrm{g} / \mathrm{ml}$ な゙は測定值に影響を与えない と Syva 社添付文書に記されている. Array 360 を用いて患者血清を測定した場合，従来広く用い られている FPIA 法および EMIT 法による測 

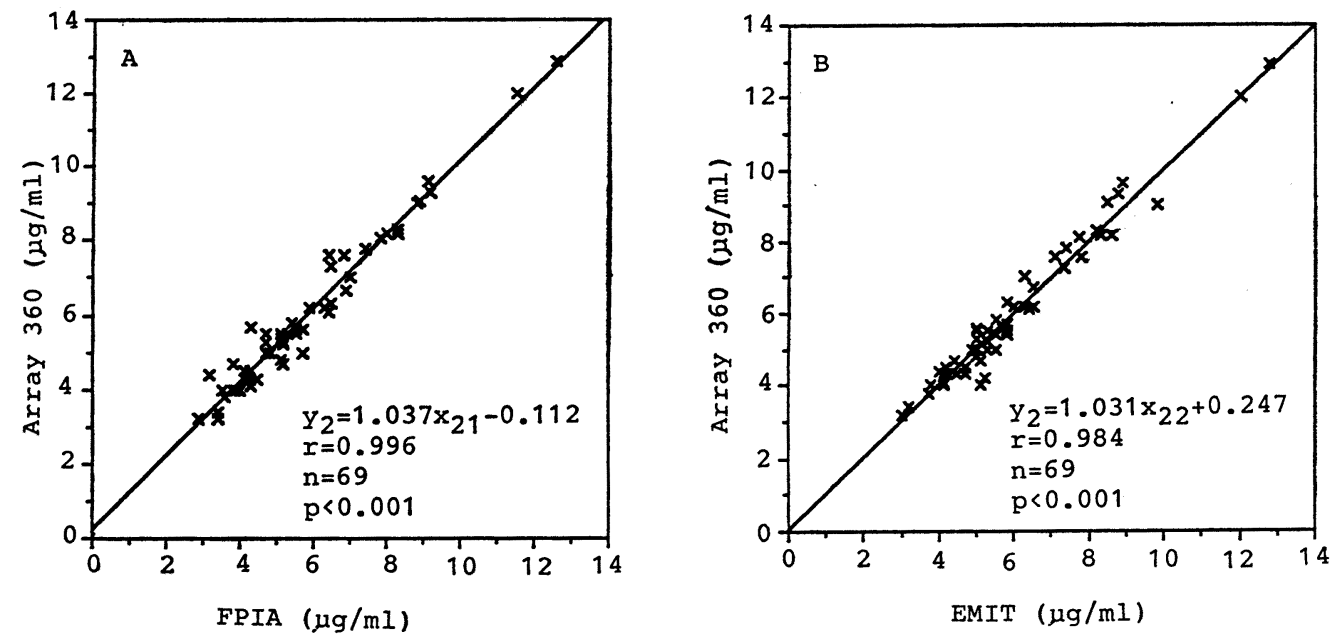

Fig. 5. Correlations among the Array 360 System, Fluoresense Polarization Immunoassay (FPIA) (A) and Homogeneous Enzyme Immunoassay (EMIT) (B) for the Determination of Carbamazepine

定値との間に有意差が認められなかったことから Array 360 の測定值には十分信頼性がある と考 える.

測定に必要な患者の血清量は FPIA 法および

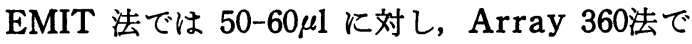
は $80 \mu 1$ とやや多いが（実質必要量； $60 \mu 1$ )，実用 上は大差ないと思われる.

各メーカーが保証する PB および $\mathrm{CBZ}$ の測定 下限值は，FPIA 法ではそれぞれ $0.65 \mu \mathrm{g} / \mathrm{ml}$ お よび $0.5 \mu \mathrm{g} / \mathrm{ml}$ に対し, Array 360 法では $5 \mu \mathrm{g} /$ $\mathrm{ml}$ および $2 \mu \mathrm{g} / \mathrm{ml}$ で, EMIT 法と同等である. 一方, 測定上限値は FPIA 法と EMIT 法では いずれもそれぞれ $80 \mu \mathrm{g} / \mathrm{ml}$ および $20 \mu \mathrm{g} / \mathrm{ml}$ に 対し, Array 360 法では高濃度の試料の場合, 自動希釈によりそれぞれ $120 \mu \mathrm{g} / \mathrm{ml}$ および $40 \mu \mathrm{g} /$ $\mathrm{ml}$ まで測定できた.

Array 360 法による測定時間は 20 検体の測定 に対し約20分と, 従来の機器と同等であった。

また Array 360 法では, 添付のキャリブレー タおよび抗血清のプログラムカードから標準曲線 などの情報を読み取ることにより，1点検量線や， 長期間の検量線保持が可能である.

さらに, Array 360 法では CPU 上で測定項 目・測定回数などを指示することにより，多種類
の項目を多数検体同時測定することが 可 能であ り，日常検査への活用が期待される.

\section{引用文 献}

1) K.W.Leal, A.J.Wilensky and R.L. Rapport, J. Anal. Toxicol., 2, 214-218 (1978).

2) H.J.Kupferberg, J. Pharm. Sci., 61, 284-286 (1972).

3) R.M.McDonald and L.L.Martan, J. Anal. Toxicol., 2, 127-133 (1978).

4) M.Eichlbaum, L. Bertilsson, J. Chromatogr., 103, 135-140 (1975).

5）宮本元昭, 平林真弓, 横溝協子, 伊藤機一, 丹羽 正治, 最新検査, 2, 76-81 (1984).

6）武藤信治, 伊藤正博, 荒川光江, 太田拔徳, 岩田 弘, 河合 忠, 臨床検査機器 ・試薬, 7, 463-466 (1984).

7) G.H. Saunders and J.K. Penry, "Practical Applications of Drug Monitoring”, Vol.2, ed. by Gross, Townsent, Frank, Inc., New York, 1981, pp.49-62.

8) J.J. MacKichan and H.Kutt, "Practical Applications of Drug Monitoring", Vol.2, ed. by Gross, Townsent, Frank, Inc., New York, 1981, pp.1-25.

9）部谷多香美, 丸井洋二, 有末一隆, 甲田一馬, 林 長蔵, 宮井 潔, 日本臨床検査自動化学会誌, 13, 726-730 (1988). 
10）宮下徹夫, 石沢 天, 橋本安男, 田中 博, 岩田 進, 河野均也, 臨床検查機器・試薬, 13, 474480 (1990).

11) M.Eichelbaum, K.Ekbom, L. Bertilsson, V. A. Ringberger and A. Rane, Eur. J. Clin. Pharmacol.; 8, 337-341 (1975).
12）西原カズョ, 太田抜徳, 武藤信治, 福山幸夫, 植 松文江, 杉山都子, 清野昌一, 籊坂昌史, 宮本㑆 治, 西村成子, 北村元仕, 化科啓, 丹羽正治, 宮本元昭, 河合 忠, 臨床検査, 28, 597-601 (1984). 